\title{
Pembaharuan UU Perseroan Terbatas dalam Kerangka Good Corporate Governance
}

\author{
Ery Arifuddin
}

\begin{abstract}
The problem of Good Governance is as the need of the Acts innovation on Company Limited. It is aimed to order that either closed or opened companies could implement the principles of Good Governance consistently. There are two important things needed of the innovation the Acts for Company Limited related to the principles of Good Governance, namely the problem of existence for independent commissioner and the problem for financial report from a Company Limited.
\end{abstract}

\section{Pendahuluan}

Good Corporate Governance atau Penabiran Korporat yang baik merupakan prinsip-prinsip dasar dalam mengupayakan sebuah perusahaan dapat menjalankan kegiatannya tanpa ada suatu penyimpangan. Prinsip tersebut meliputi; prinsip fairness, transparancy, accountability, dan responsibility.

Mengingat pentingnya penerapan prinsip good corporate governance, maka untuk mengimplementasikan tidak sebatas pada pengaturan dalam bentuk Surat Keputusan Menteri, tetapi lebih dari itu perlu dituangkan dalam setiap peraturan yang terkait dengan perusahaan.

Rencana pembaharuan UU No. 1 Tahun 1995 tentang Perseroan Terbatas ${ }^{1}$ pada hakekatnya adalah momentum yang sangat penting untuk memperbaharui UU Perseroan Terbatas yang didasarkan pada prinsip good corporate governance. Maksud dan tujuan prinsip good corporate governance diakomodasikan dalam UU Perseroan Terbatas supaya segala sesuatu yang berkaitan dengan sebuah perseroan terbatas dapat dilihat dengan transparan, dapat dipertanggungjawabkan yang pada akhirnya memacu kepada pertumbuhan dan perkembangan perusahaan yang sehat.

Sekilas nampak bahwa UU Perseroan Terbatas masih banyak memberikan celah kepada para pelaku perușahaan, sehingga hal yang wajar apabila banyak perusahaan di

'Selanjutnya UU No. 1 Tahun 1995 tentang Perseroan Terbatas dalam tulisan ini disebut UU Perseroan Terbatas. 
Indonesia dalam melaksanakan kegiatan operasionalnya tidak tunduk dan taat pada ketentuan UU Perseroan Terbatas. Kondisi ini semakin kentara ketika krisis ekonomi menerpa Indonesia. Perusahaan-perusahaan di Indonesia baik yang sifatnya milik pemerintah maupun swasta mengalami kebangkrutan akibat tidak diterapkannya prinsip good corporate governance.

\section{Pengertian dan Tata Cara Pendirian Perseroan Terbatas}

Istilah Perseroan Terbatas (PT) yang digunakan dewasa ini dulunya dikenal dengan istilah Naamloze Vennootschap (NV). ${ }^{2}$ Bagaimana asal muasal digunakannya istilah Perseroan Terbatas dan disingkat dengan PT tidak dapat ditelusuri, tetapi sebutan tersebut telah menjadi baku di dalam masyarakat bahkan juga dibakukan di dalam UU No. 1 Tahun 1995 tentang Perseroan' Terbatas. ${ }^{3}$

Bentuk Perseroan Terbatas (PT) merupakan bentuk yang lażim dan banyak dipakai dalam dunia usaha di Indonesia karena PT merupakan asosiasi modal dan badan hukum yang mandiri. ${ }^{4}$

Pengertian' Perseroan Terbatàs sendiri dapat ditemukan dalam ketentuan Pasal 1 angka 1 yang menyatakan bahwa Perseroan Terbatas yang selanjutnya disebut perseroan adalah: badan hukum yang didirikan berdasarkan perjanjian, melakukan kegiatan usaha dengan modal dasar yang seluruhnya terbagi dalam saham, dan memenuhi persyaratan yang ditetapkan dalam undangundang ini serta peraturan pelaksanaannya.

Dari pengertian ini dapat diklasifikasi unsur-unsur dari perseroan. Unsur-unsur itu meliputi: 1) badan hukum; 2) didirikan berdasarkan perjanjian; 3) melakukan kegiatan usaha; 4) modal dasar terdiri dari sahamsaham; 4) harus memenuhi persyaratan undang-undang dan peraturan pelaksanaan yang terkait.

Sementara itu perseroan dapat juga dipersamakan dengan istilah legal entity atau artificial law. Menurut Kamus Black's Law Dictionary legal entity adalah: ${ }^{5}$

Legal existence, an entity other than a natural person, who has sufficient existence in legal contemplation that it can function legally, be sued or sue and make decisions through agents as in the case of corporations.

Perseroan sebagai badan hukum artinya syarat materil maupun formil dari badan hukum telah dipenuhi oleh perseroan. Sebuah

\footnotetext{
${ }^{2}$ Charles Himawan menyatakan, "The Code uses instead the term Naamloze Vennootschap, i.e associafion without a name derived from the French term Societe Anonyme (SA). Although the designation N.V. an abbreviation of the Dutch term Naamloze Vennootschap is still used, the designation PT (for Perseroan Terbatas-Limited (liability) Company) is now more common. "Lihat dalam Charles Himawan. "Business Law: Contract and Business Associations" Survey of Indonesian Economic Law Padjadjaran Universty Faculty of Law. Bandung: Lembaga Penelitian Hukum dan Kriminologi FH UNPAD, hlm. 40.

${ }^{3}$ H.M.N. Purwosutjipto. 1981. Pengertian Pokok Hukum Dagang Indonesia. Jakarta: Djambatan. Him. 85 Dikutip dari Ridwan Khairandy, et. al. 1999. Pengantar Hukum Dagang Indonesia I. Yogyakarta: Pusat Studi Hukum FH Ull. HIm 4.

${ }^{4}$ I.G. Rai Widjaya. 2000. Hukum Perusahaan Perseroan Terbatas. Jakarta: Megapoin. HIm.1

${ }^{5}$ Henry Campbell Black. 1991. Black's Law Dictionary. USA: St Paul Minn. HIm. 456.
} 
badan usaha dapat berbentuk badan hukum apabila dipenuhi syarat-syarat dari badan hukum itu sendiri. Ada berberapa syarat. yang harus dipenuhi, yakni::

\section{Adanya harta kekayaan terpisah}

Harta kekayaan ini diperoleh dari para anggota maupun perbuatan pemisahan yang dilakukan seorang/partikelir/pemerintah untuk suatu tujuan tertentu. Adanya harta. kekayaan ini dimaksudkan sebagai alat untuk mencapai apa yang menjadi tujuan badan hukum yang bersangkutan. Harta kekayaan ini meskipun berasal dari pemasukan-pemasukan anggotaanggotanya, namun terpisah dengan harta kekayaan kepunyaan pribadi anggotaanggotanya itu.

\section{Mempunyai tujuan tertentu}

Tujuan tertentu ini dapat berupa tujuan yang idiil maupun tujuan komersiil yang merupakan tujuan tersendiri daripada badan hukum. Jadi bukan tujuan untuk kepentingan satu atau beberapa anggotanya. Usaha untuk mencapai tujuan tersebut dilakukan sendiri oleh badan hukum dengan diwakili organnya.

\section{Mempunyai kepentingan sendiri}

Dalam mencapai tujuannya, badan hukum mempunyai kepentingan sendiri yang dilindungi oleh hukum. Kepentingankepentingan tersebut merupakan hak-hak subjektif sebagai akibat dari peristiwaperistiwa hukum. Oleh karena itu. badan hukum mempunyai kepentingan sendiri, dan dapat menentukan serta mempertahankannya terhadap pihak ketiga dalam pergaulan hukumnya.

\section{Adanya organisasi yang teratur}

Badan hukum adalah suatu konstruksi yuridis. Karena itu sebagai subjek hukukum di samping manusia, badan hukum hanya dapat melakukan perbuatan hukum dengan perantaraan organnya.

Di samping persyaratan di atas, ada juga yang mempersyaratkan lain bahwa badan usaha dapat menjadi badan hukum apabila mendapat pengakuan dari pemerintah berupa pengesahan dari pemerintah dalam hal ini Menteri Kehakiman.

Dengan status perseroan sebagai badan hukum, maka peíseroan menjadi subjek hukum yang menjadi pendukung hak dan kewajiban. Perseroan memiliki kedudukan mandiri (persona standi in judicio) yang tidak térgantung kepada pemegang sahamnya. Perseroan juga harus organ yang dapat mewakili Perseroan yang menjalankan perusahaan. $^{7}$

Dengan demikian, perseroan dapat melakukan perbuatan-perbuatan hukum seperti seorang manusia dan dapat pula mempunyai kekayaan atau utang (ia bertindak dengan perantaraan pengurus. Walaupun suatu badan hukum itu bukanlah seorang manusia yang mempunyai pikiran/kehendak, akan tetapi menurut hukum ia dapat dianggap mempunyai kehendak. Menurut teori yang

${ }^{6}$ Ridwan Syahrani. 1999. Rangkuman Intisarillmu Hukum. Bandung: Citra Aditya Bakti. HIm. 151-152. Bandingkan dengan Chaidir Ali. 1999. Badan hukum. Bandung: Alumni. Hlm. 79-92.

'Ery Arifuddin. "Tanggung Jawab Direksi dalam Pembelian Kembali Saham oleh Perseroan Terbatas." Jurnal Hukum dan Keadilan Vol. 2 No. 1 Oktober 1999. Him. 24. 
lazim dianut, kehendak dari persero pengurus dianggap sebagai kehendak perseroan. Akan tetapi, perbuatan-perbuatan pengurus yang bertindak atas nama perseroan, pertanggungjawabannya terletak pada perseroan dengan semua harta bendanya. ${ }^{8}$

Selain perseroan memiliki unsur badan hukum, perseroan juga mempunyai unsur di mana didirikan berdasarkan perjanjian. Masalah pérjanjian ini sangat terkait dengan tata cara pendirian perseroan. Menurut Abdul Kadir Muhammad untuk mendirikan sebuah perseroan setidaknya ada 5 tahap yang harus dilakukan, yakni:9

\section{Pembuatan perjanjian tertulis}

Para pendiri perseroan membuat perjanjian untuk mendirikan perseroan. Perjanjian tersebut berisi antara lain mengenai susunan dan penyertaan modal, susunan saham, penunjukan Direksi dan Komisaris perbuatan hukum dengan pihak ketiga, yang selanjutnya disusun dalam bentuk Anggaran Dasar perseroan. Supaya perjanjian yang dibuat itu sah, maka ketentuan Pasal 1320 KUHPdt harus dipenuhi. Perjanjian ini merupakan perjanjian pendahuluan.

Perjanjian pendahuluan ini kemudian disusun dalam bentuk Anggaran Dasar. Ketentuan Anggaran Dasar yang mengatur kegiatan perseroan tidak boleh bertentangan dengan peraturan perundang-undangan, ketertiban umum, dan atau kesusilaan (Pasal 2 UU Perseroan Terbatas).
2. Pembuatan akta pendirian di muka Notaris

Para pendiri yang telah membuat perjanjian itu kemudian pergi menghadap notaris untuk minta dibuatkan akta pendirian perseroan. Sejak akte pendirian ditandatangai oleh para pendiri adalah hubungan kontrak, sebelum perseroan memperoleh status badan hukum.

\section{Pengesahan oleh Menteri Kehakiman}

Untuk memperoleh pengesahan, para pendiri atau kuasanya mengajukan permohonan tertulis kepada Menteri Kehakiman dengan melampirkan akta pendirian perseroan. Pengesahan akta pendirian diberikan dalam waktu paling lama 60 hari setelah permohonan diterima. Dalam hal permohonan ditolak, penolakan tersebut harus diberitahukan kepada pemohon secara tertulis beserta alasannya dalam waktu paling lama 60 hari (Pasal 9. UU Perseroan Terbatas). Jangka waktu 60 hari terhitung sejak permohonan yang diajukan dinyatakan telah memenuhi syarat dan kelengkapan yang diperlukan sesuai dengan ketentuan yang berlaku.

Perseroan memperoleh status badan hukum setelah akta pendirian disahkan oleh Menteri Kehakiman (Pasal 7 ayat (6) UU Perseroan Terbatas). Sejak pengesahan, perseroan adalah badan yang mandiri, sehingga menurut ketentuan Pasal 3 ayat (1) UU Perseroan Terbatas, pendiri sebagai pemegang saham perseroan tidak bertanggung jawab secara pribadi atas perikatan yang dibuat atas nama perseroan dan tidak

${ }^{8}$ C.S.T Kansil. 1995. Hukum Perusahaan Indonesia (Aspek Hukum dalam Ekonomi). Jakarta: PT. Pradnya Paramita. HIm. 23.

'Abdul Kadir Muhammad. 1999. Hukum Perusahaan. Bandung: Citra Aditya Bakti. HIm.'14-20. 
bertanggung jawab atas kerugian perseroan melebihi nilai saham yang telah diambil.

\section{Pendaftaran Perseroan}

Direksii wajib mendaftarkan dalam Daftar Perusahaan akta pendirian beserta surat pengesahan Menteri Kehakiman. Pebdaftaran wajib dilakukan dalam waktu paling lambat 30 hari setelah pengesahan diberikan (Pasal 21 UU Perseroan Terbatas), Daftar Perusahaan adalah Daftar Perusahaan yang dimaksud dalam UU No. 3 Tahun 1982 tentang Wajib Daftar Perusahaan.

\section{Pengumuman dalam Tambahan Berita Negara}

Menurut ketentuan Pasal 22 UU Perseroan Terbatas, perseroan yang telah didaftarkan diumumkan dalam Tambahan Berita Negara RI. Permohonan pengumuman perseroan dilakukan oleh Direksi dalam waktu paling lambat 30 hari terhitung sejak pendaftaran, sesuai dengan tata cara yang telah diatur oleh perundang-undangan yang berlaku.

Dari pengertian dan tahap-tahap pendirian perseroan memiliki karkateristik sendiri, jika dibandingkan dengan bentuk perusahaan lainnya. Perseroan nampak dari segi perangkat hukum sangat tertata sekali, sehingga apabila ada aturan yang tidak ditaati berkaitan dengan perseroan, maka akan mempunyai konsekuensi terhadap eksistensi perseroan itu sendiri.

\section{Organ-organ Perseroan Terbatas}

Dalam operasionalisasinya perseroan sebagai badan hukum tentunya tidaklah melakukan perbuatan hukum sendiri, tetapi dalam hal ini perseroan diwakili oleh organorgan perseroan. Pasal 1 Butir 2 UU Perseroan Terbatas secara tegas menyebutkan bahwa organ perseroan terdiri dari 1) Rapat Umum Pemegang Saham (RUPS); 2) Diréksi, dan; 3) Komisaris.

Rapat umum pemegang saham adalah kekuasaan tertinggi dalam perseroan dan memegang segala wewenang yang tidak diserahkan kepada direksi atau komisaris. Kewenangan yang tidak diserahkan kepada direksi atau komisaris adalah:10

1. Mengubah anggaran dasar (Pasal 14);

2. Membeli kembali saham yang telah dikeluarkan, kecuali RUPS menyerahkannya kepada orang lain, yakni direksi atau komisaris (Pasal 31-32);

3. Menambah modal perseroan, kecuali RUPS menyerahkannya kepada komisaris (Pasal 34);

4. Mengurangi modal perseroan (Pasal 37);

5. Memberikan persetujuan Laporan Tahunan dan Pengesahan Laporan Keuangan atau Perhitungan Tahunan (Pasal 60);

6. Menggunakan laba bersih, termasuk penentuan jumlah yang disisihkan untuk cadangan (Pasal 62);

7. Memperoleh segala keterangan yang berkaitan dengan kepentingan perseroan dari direksi dan atau komisaris (Pasal 63);

${ }^{10 H a r j j a n ~ R u s l i . ~ 1996 . ~ P e r s e r o a n ~ T e r b a t a s ~ d a n ~ A s p e k ~ H u k u m n y a . ~ J a k a r t a: ~ P u s t a k a ~ S i n a r ~ H a r a p a n . ~}$ HIm. 114-115. Dikutip dari Ridwan Khairandy. Op.Cit. HIm. 48-49. 
8. Mengangkat anggota Direksi (Pasal 80);

9. Menetapkan pembagian tugas dan wewenang setiap anggota direksi șerta jenis penghasilan direksi, kecuali jika dilimpahkan kepada komisaris (Pasal 81);

10. Memberikan persetujuan. untuk mengalihkan atau menjadikan jaminan utang. seluruh atau sebagian besar kekayaan perseroan (Pasal 88);

11. Memberikan keputusan untuk mengajukan permohonan pernyataan kepailitan kepada pengadilan negeri (Pasal 90);

12. Sewaktu-waktu memberhentikan anggota direksi dengan menyebutkan alasannya (Pasal 92);

13. Mengangkat komisaris (Pasal 95);

14. Memberhentikan komisaris secara tetap atau sementara (Pasal 101);

15. Menyetujui rancangan penggabungan dan peleburan' perseroan (Pasal '102);

16. Memberikan persetujuan pengambilalihan (Pasal. 103);

17. Memberikan keputusan pembubaran perseroan (Pasal 115);

18. Menerima pertanggungjawab likuidator atas likuidasi yang dilakukannya (Pasal 124).

RUPS diadakan di tempat kedudukan perseroan. Dalam Anggaran Dasar dapat ditetapkan bahwa RUPS dapat dilakukan di luar tempat kedudukan perseroan atau kecuali ditentukan lain dalam Anggaran .Dasar tetapi harus terletak di wilayah negara Republik Indonesia. ${ }^{11}$.
Sementara itu RUPS dapat dibedakan menjadi dua bagian. Pertama RUPS tahunan diadakan dalam waktu paling lambat 6 (enam) bulan setelah tahun buku, dan dalam RUPS tahunan tersebut harus diajukan semua dokumen perseroan. Kedua, RUPS lainnya, diadakan sewaktu-waktu berdasarkan kebutuhan. ${ }^{12}$

Mekanisme RUPS tahunan dan RUPS lainnya diselenggarankan oleh direksi. Penyelenggaran RUPS ini juga dapat dilakukan atas permintaan 1 (satu) pemegang saham atau lebih yang bersama-sama mewakili $1 / 10$ (satu persepuluh) bagian dari jumlah,seluruh saham dengan hak suara yang sah, atau suatu jumlah yang lebih kecil sebagaimana ditentukan dalam Anggaran Dasar perseroan yang bersangkutan.

Permintaan ini diajukan kepada Direksi atau Komisaris dengan surat disertai alasannya.'Apabila Direksi atau Komisaris tidak mau menyelenggarakan RUPS, maka pemegang saham dapat mengajukan permohonan kepada Ketua Pengadilan Negeri yang daerah hukumnya meliputi tempat kedudukan perseroan untuk:

1. Melakukan sendiri pemanggilan RUPS tahunan, atau permohonan pemegang saham pabila direksi atau komisaris tidak menyelenggarakan RUPS tahunan pada waktu yang telah ditentukan; atau

2. Melakukan sendiri pemanggilan RUPS lainnya, atau permohonan pemegang saham, apabila direksi atau komisaris setelah lewat waktu 30 (tigapuluh) hari

11.G.Rai Widjaya. Op.Cit. Hlm.56.

${ }^{12}$ /bid. 
terhitung sejak permintaan tidak melakukan pemanggilan RUPS lainnya.

Ketua Pengadilan Negeri dapat menetapkan bentuk, isi dan jangka waktu pemanggilan RUPS serta menunjuk ketua rapat tanpa terikat UU Perseroan Terbatas atau Anggaran Dasar. Bentuk penetapan dari Ketua Pengadilan Negeri merupakan instansi pertama dan terakhir.

Untuk menyelenggarakan RUPS Direksi melakukan pemanggilan kepada pemegang saham. Dalam hal-hal tertentu dapat juga dilakukan pemanggilan oleh Komisaris. Halhal tertentu yang dimaksudkan bahwa pada hakekatnya pemanggilan RUPS adalah kewajiban Direksi. Namun, dalam hal Direksi berhalangan atau ada pertentangan kepentingan antara Direksi dan perseroan pemanggilan RUPS dapat dilakukan oleh Komisaris.

Pemanggilan RUPS dilakukan paling lambat 14 hari sebelum RUPS diadakan. Bentuk pemanggilan dilakukan dengan surat tercatat, khusus untuk RUPS Perseroan Terbuka pemanggilan RUPS dilakukan dalam 2 (dua) surat kabarharian. Akan tetapi sebelum pemanggilan melalui dua surat kabar ini, maka wajib bagi didahului dengan pengumuman mengenai akan diadakan pemanggilan RUPS dalam 2 (dua) surat kabar harian. Jangka waktunya 14 (empat belas) hari sebelum pemanggilan RUPS. Dalam hal pemanggilan RUPS, maka perseroan wajib memberikan salinan bahan kepada pemegang saham secara cuma-cuma.

RUPS dapat dilangsungkan apabila dihadiri oleh pemegang saham.yang mewakili lebih dari $1 / 2$ (satu perdua) bagian dari jumlah seluruh saham dengan hak suara yang sah, kecuali UU Perseroan Terbatas atau Anggaran
Dasar menentukan lain. Seandainya korum ini tidak dicapai dapat dilakukan pemanggilan RUPS kedua. Waktunya paling lambat 7 hari sebelum RUPS kedua diselenggarakan. Untuk penyelenggaraan RUPS kedua sendiri UU Perseroan Terbatas menentukan bahwa paling cepat 10 (sepuluh) hari paling lambat 21 (duapuluh satu) hari dari RUPS pertama.

RUPS kedua sah dan berhak mengambil keputusan apabila dihadiri oleh pemegang saham yang mewakili paling lama sedikit $1 / 3$ (satu pertiga) bagian dari jumiah seluruh saham derigan hak suara penuh. Kalau jumlah korum tidak dipenuhi, maka Ketua Pengadilan Negeri dapat menetapkan atas permohonan perseroan korum. Penetapan dapat didelegasikan kepada pejabat lain yang mewakili Ketua Pengadilan Negeri, apabila KPN berhalangan.

Keputusan RUPS dapat diambil melalui dua cara. Pertama, melalui musyawarah untuk mufakat. Kedua, keputusan dapat diambil berdasarkan suara terbanyak biasa dari jumlah suara yang dikeluarkan. Harus diperhatikan jika UU Perseroan Terbatas atau Anggaran Dasar menentukan lain, maka undangundang atau anggaran dasar itulah yang harus diikuti.

Dalam penjelasan Pasal 74 ayat (2) dinyatakan pada dasarnya semua keputusan RUPS harus dicapai melalui musyawarah dan mufakat. Apabila setelah diusahakan musyawarah untuk mufakat tidak dapat dicapai, keputusan RUPS dapat diambil melalui pemungutan suara dengan suara terbanyak. Secara umum suara terbanyak yang diperlukan adalah suara terbanyak biasa yaitu jumiah suara yang lebih banyak dari kelompok suara lain, tanpa harus mencapai dari lebih setengah keseluruhan suara dalam 
pemungutan suara tersebut. Namun demikian, dalam hal-hal tertentu keputusan RUPS yang berkaitan dengan sesuatu yang sangat mendasar bagi keberadaan, kelangsungan atau sifat suatu perseroan, undang-undang ini atau anggaran dasar dapat menentapkan suara terbanyak yang lebih besar dari suara terbanyak biasa; yaitu suara terbanyak mutlak (absolute majority) atau suara terbanyak khusus (qualified/special majority), Suara terbanyak mutlak adalah suara terbanyak yang lebih dari $1 / 2$ (satu perdua) dari seluruh jumlah suara dalam pemungutan suara tersebut. Suara terbanyak khusus adalah suara terbanyak yang ditentukan secara pasti jumlahnya secara pasti $2 / 3$ (dua pertiga), $3 / 4$ (tiga perempat), $3 / 5$ (tiga perlima) dan sebagainya.

Komentar Sudargo terhadap pejelasan ini, ia mengatakan bahwa istilah bahasa Inggris agak mengherankan mengapa hal itu dianggap-perlu untuk dipakai bahasan asing, padahal bahasa Indonesia saja sudah cukup memadai dan dimengerti. Di sisi lain istilah itu tidak biasa dalam kamus peristilahan UU Perseroan Terbatas yang hingga kini berlaku. Apakah ini adalah pengaruh dari iklim "hukum anglosaxon" yang hendak dimasukan juga oleh pembuat UU Perseroan Terbatas baru. ${ }^{13}$ $\therefore$ Organ lainnya dari perseroan adalah Direksi. Direksi adalah organ perseroan yang bertanggungjawab penuh atas pengurusan perseroan untuk kepentingan dan tujuan perseroan: serta mewakili perseroan baik di dalam maupun di fuar Pengadilan sesuai dengan ketentuan Anggaran Dasar. ${ }^{14}$

Pengerian pengurusan mencakup pula pengelolaan, kekayaan perseroan, karena itu UU Perseroan Terbatas mengatur mekanisme yang memungkinkan terlaksananya prinsip fiduciary duty yang. mencakup juga duty of skill and care oleh Direksi. Hal ini tampak pada pengaturan tugas masing-masing anggota Direksi, bahkan apabila anggota Direksi yang bersangkutan bersalah atau lali melaksanakan tugasnya dengan baik sehingga perseroan dirugikan, dia bertanggungjawab penuh secara pribadi, dan pemegang saham dapat mengajukan gugatan ke Pengadilan Negeri. ${ }^{15}$

Mengingat beratnya tanggung jawab Diréksi, maka untuk menjabat menjadi anggota Direksi ada beberapa persyaratan yang harus dipenuhi: ${ }^{16}$

1. Bahwa ia memang mampu melaksanakan perbuatan hukum. Artinya ia tidak berada dalam pengampuan atau curatele;

2. la juga tidak pernah dinyatakan pailit, dari dahulu sampai sekarang. Tidak tercatat sebagai orang yang bangkrut dan telah dinyatakan pailit;

3. Menjadi anggota Direksi atau Komisaris yang telah - dinyatakan bersalah menyebabkan suatu perseroan dinyatakan pailit;

4. Atau orang yang pernah dihukum, pernah dihukum, karena melakukan tidak pidana

${ }^{13}$ Sudargo Gautama. 1995. Komentar Atas Undang-Undang Perseroan Terbatas (Baru) Tahun 1995 No. 1 Perbandingan dengan Peraturan Lama. Bandung: Citra Aditya Bakti: HIm.82.

${ }^{14} \mathrm{Abdulkadir}$ Muhammad. 1996. Hukum Perseroan Indonesia. Bandung: Citra Aditya Bakti. HIm. 29.

$\therefore{ }^{15} /$ bid : ;

${ }^{16}$ Sudargo.Gautama. Op.Cit, HIm. 85-86. 
yang merugikan keuangan negara dalam waktu lima tahun sebelum pengangkatan.

Pasal 84 UU Perseroan Terbatas menentukan pembatasan wewenang Direksi. Menurut ketentuan pasal ini, anggota Direksi tidak berwewenang mewakili perseroan apabila:

1. terjadi perkara di depan pengadilan antara perseroan dengan anggota Direksi yang bersangkutan; atau

2. anggota Direksi yang bersangkutan mempunyai kepentingan yang bertentangan dengan kepentingan perseroan.

Selanjutnya Pasal 85 UU Perseroan Terbatas menyatakan bahwa setiap anggota Direksi wajib dengan iktikad baik dan penuh dengan tanggung jawab menjalankan tugas dengan kepentingan dan usaha perseroan. Setiap anggota Direksi bertanggung jawab penuh secara pribadi apabila yang bersangkutan bersalah atau lalai menjalankan tugasnya. Atas nama perseroan, pemegang saham yang mewakili paling sedikit $1 / 10$ (satu persepuluh) bagian dari jumlah seluruh saham dengan hak suara yang sah dapat mengajukan gugatan ke Pengadilan Negeri terhadap anggota Direksi yang karena kesalahan atau kelaliannya menimbulkan kerugian kepada perseroan.

Dalam garis besarnya ada dua macam kewajiban Direksi, yaitu kewajiban Direksi yang berkaitan dengan perseroan, dan kewajiban Direksi yang berkaitan dengan RUPS. Berikut ini akan diuraikan keduanya: ${ }^{17}$
1. Kewajiban Direksi yang berkaitan dengan perseroan

a. Mengusahakan pendaftaran Akte Pendirian atau akte perubahan Anggaran Dasar Perseroan secara lengkap disertai SK pengesahan atau SK persetujuan dalam Daftar Perusahaan sesuai dengan ketentuan Wajib Daftar Perusahaan paling lambat, tigapuluh hari setelah pengesahan atau persetujuan diberikan dan mengusahakan pengumuman perseroan yang telah didaftarkan tersebut dalam Tambahan Berita Negara RI paling lambat tigapuluh hari setelah pendaftaran dilakukan (Pasal' 21 dan 22).

b. Mengadakan dan menyimpan daftar pemegang saham dan daftar khusus yang memuat keterangan mengenai kepemilikan saham dari anggota Direksi/Komisaris beserta keluarganya pada perseroan tersebut atau pada perseroan lain. (Pasal 43).

c. Mendaftarkan atau mencatat setiap pemindahan hak atas saham disertai dengan tanggal dan hari pemindahan hak dalam daftar Pemegang Saham atau Daftar Khusus (Pasal 49 ayat (3)).

d. Dengan iktikad baik dan penuh tanggung jawab menjalankan tugas pengurusan perseroan untuk kepentingan dan usaha perseroan (Pasal 82 Jo Pasal 185).

e. Menyelenggarakan pembukuan perseroan (Pasal 86 ayat (1) huruf b).

${ }^{17}$ Anisitus Amanat. 1995. Pembahasan Undang-Undang Perseroan Terbatas 1995 dan Penerapannya dalam Akta Notaris. Jakarta: Raja Grafindo Persada. Hlm.130-132. 
f. Direksi atau anggota Direksi Wajib melaporkan kepada perseroan mengenai kepemilikan sahamnya beserta keluarganya pada perseroan tersebut dan perseroan lain (Pasal 87):

2... Kewajiban Direksi yang berkaitan dengan RUPS

a: Minta persetujuan RUPS jika persèroan ingin membeli saham yang telah dikeluarkan.

b. Minta persetujuan RUPS jika perseroan ingin menambah atau mengurangi besarnya jumlah modal perseroan.(Pasal 34 jo Pasal 37).

c. Menyampaikan laporan tahunan (Pasal 56).

d. Menandatangani laporan tahunan sebelum disampaikan kepada RUPS (Pasal 57).

e. Menyampaikan laporan secara tertulis tentang perhitungan tahunan perșeroan yang telah diperiksa akuntan publik (Pasal 59 ayat (3)).

f. Pada saat diselenggarakan RUPS, Direksi mengajukan semua dokumen perseroan (Pasal 65).

g. Menyelenggarakan panggilan RUPS (Pasal 68 dan penjelasannya)

h. Minta persetujuan RUPS jika hendak melakukan tindakan hukum pengalihan atau menjadikan jaminan utang atas seluruh atau sebagian besar asset perseroan (Pasal 88).

i. Menyusun rancangan-łancangan penggabungan, peleburan dan' pengambilalihan untuk disampaikan kepada. RUPS guna mendapatkan keputusan (Pasal 102 jo Pasal 103).

j. Mengumümkan dalam surat kabar harian tentang rencana penggabungan, peleburan, dan 'pengambilalihan perseroan' paling 'lambat 14 (empatbelas) hari sebelúm pemanggilan RUPS dilakukan (Pasal 103 jo Pasal 105).

Di samping kewajiban yang berkaitan dengan perseroan dan RUPS, Direksi juga mempunyai kewajiban yang berkaitan dengan kepentingan kreditur atau masyarakat umum. Pertama, memberitahukan rencana dan hasil rencana penggabungan, peleburan, dan pengambilalihan PT (Pasal 105 jo 108). Kedua, memberitahukan tentang pembubaran perseroan (Pasal 120). Ketiga, memberikan segala keterangan tentang perseroan yang diperlukan petugas pemeriksa (Pasal 111) dan membayar biaya pemeriksaan atas nama perseroan (Pasal 113)..$^{18}$

Dalam hal pemberhentian Direksi, UU Perseroan Terbatas mengaturnya dalam Pasal 91 dan Pasal 92 ÚU Perseroan Terbatas. Pasal 91 ayat (1), (2). Dan (3) UU Perseroan Terbatas menyatakan:

(1) Anggota Direksi dapat sewaktu-waktu diberhentikan berdasarkan keputusan RUPS dengan menyebutkan alasannya.

(2) Keputusan untuk memberhentikan anggota Direksi sebagaimana dimaksud dalam ayat (1) hanya dapat diambil setelah yang bersangkutan diberi kesempatan untuk membela diri dalam RUPS.

${ }^{18} / \mathrm{bid}$. 
(3) Dengan keputusan pemberhentian sebagaimana dimaksud dalam ayat (2), maka kedudukannya sebagaimana anggota Direksi berakhir.

Menurut ketentuan ini, maka anggota Direksi dapat saja diberhentikan dengan menyebutkan aläsañ. Sejalan dengan itu pula anggota Dïreksi harus diberi kesempatan untuk membela diri. Kalau anggota Direksi itu tidak hadir RUPS dapat memberhentikan tanpa kehadirannya. Apabila putusan pemberhentian itu sudah dikeluarkan saat itu juga anggota Direksi berakhir.

Pasal 92 UU Perseroan Terbatas mengatur tentang pemberhentian yang sifatnya sementara. Prosedur dan mekanișmenya hampir sama dengan pemberhentian yang sifatnya absolut. Penambahannya anggota Direksi yang akan diberhentikan sementara harus diberitahu secara tertulis. Anggota Direksi yang diberhentikàn sementara tidak berwenang melakukan tugasnya. Setelah pemberhentian sementara anggota Direksi dalam waktu paling lambat 30 (tiga puluh) hari harus diadakan RUPS. Dalam RUPS resebut anggota Direksi' diberikan kesempatan' untuk membela diri. ${ }^{19}$

Kàlau dalam RUPS itu pembelaan diri anggota Direksi diterima, maka RUPS dapat mencabut keputusan memberhentikan sementara, tetapi sebaliknya jika tidak diterima pembelaan diri itu akan mengakibatkan anggota Direksi bersangkutan diberhentikan.

Organ terakhir dari perseroan; yakni Komisaris. Perkataan "Komisaris" mengandung pengertian, baik sebagai "organ" maupun sebagai "orang perseorangan." Sebagai "organ" Komisaris lazim juga disebut' Dewan Komisaris, sedangkán sebagai "orang perseorangan" disebut anggota Komisaris. Dewan Komisaris adalah badan/organ pengawas mandiri yang tidak dikenál dalam. system hukum perseroan Anglo-Amerika. Kalaupun Board of Directors perseroan dalam system Common Law memberi kesan mirip dengan Dewan Komisaris, namun demikian kemiripan tersebut semu karena pada hakekatnya Board of Directors adalah organ eksekutif.. Juga istilah officer yang tidak dikenal dalam system kontinental. ${ }^{20}$

Pasal 95 UU Perseroan Terbatas mengatur tentang pengisian jabatan Komisaris. Pasal tersebut menyatakan:

(1) Komisaris diangkat oleh RUPS.

(2) Untuk pertama kali pengangkatan Komisaris dilakukan dengan mencantumkan susunan dan nama Komisaris dalam Akta Pendirian sebagaimana dimaksudkan dalam Pasal 8 ayat (1) huruf $b$.

(3). Komisaris diangkat untuk jangka waktu tertentu dengan kemungkinan diangkat kembali.

\footnotetext{
${ }^{19}$ Sebagai catatan kalau dalam waktu tiga puluh hari tidak diadakan RUPS pemberhentian sementara tersebutbatal.

${ }^{20}$ Chatamarrasjid. 2000. Menyingkap Tabir Perseroan (Piercing The Corporate Veil) Kapita Selekta Hukum Perusahaan. Bandung: Citra Aditya Bakti. HIm. 48. Pembahasan Komisaris dapat dilihat secara lebih lengkap pada Moenaf H. Tegar. 2000. Dewan Komisaris Peranannya sebagai Organ Perseroan. Jakarta: Bumi Aksara.
} 
(4) Anggaran Dasar mengatur tata cara 'pencalonan, pengangkatan, dan pemberhentian Komisaris tanpa mengurangi hak pemegang saham dalam pencalonan.

Berdasarkan ketentuan ayat (4) tersebut di atas, para pendiri perlu menetapkan prosedur pengangkatan dan pemberhentian Komisaris atau anggota Komisaris secara mendetail di dalam Akte Pendirian/ Anggaran Dasar guna mencegah hal-hal yang tidak diinginkan berkaitan dengan pengisian jabatan Komisaris dalam perseroan atau menciptakan kepastian hukum pengisian jabatan Komisaris. ${ }^{21}$

UU Perseroan Terbatas menugaskan Komișaris untuk mengawasi kebijaksanaan Direksi dalam menjalankan perseroan serta memberikan nasihat kepada Direksi perseroan. Pada umumnya, dalam praktik kegiatan perseroan, Komisaris diberikan kewenangan untuk menyetujui atau tidak menyetujui tindakan-tindakan tertentu yang akan dilakukan oleh Direksi perseroan, termasuk untuk menyetujui Laporan Tahunan yang akan disampaikan kepada pemegang saham untuk dibahas dalam RUPS Tahunan perseroan. ${ }^{22}$

Selain itu UU Perseroan Terbatas membuka kemungkinan bagi Komisaris untuk dalam halhal tertentu (seperti dalam halnya terdapat pertentangan kepentingan antara Direksi perseroan dan perseroan, atau dalam hal terjadi kelowongan jabatan Direksi dalam perseroan) untuk bertindak mewakili perseroan dan bertindak untuk dan atas nama perseroan. Dalam hal yang demikian, maka ketentuan yang berlaku bagi Direksi perseroan berlaku pula bagi Komisaris perseroan. ${ }^{23}$

Ada tiga macam kewajiban Komisaris. Pertama, mengawasi Direksi dalam menjalankan tugas pengurusan perseroan selaku pelaksana harian tugas-tugas para pemegang saham dalam perseroan atau selaku wakil dari seluruh pemegang saham. Dalam melaksanakan tugas tersebut Komisaris bertindak untuk kepentingan perseroan (Pasal 97 jo Pasal 98). Kedua, kewajiban untuk memberikan nasihat-nasihat kepada Direksi sejauh dipandangnya perlu atau sejauh diminta Direksi (Pasal 97) dan ketiga, kewajiban untuk melaporkan kepada perseroan mengenai kepemilikan sahamnya beserta keluarganya pada perseroan tersebut dan perseroan lainnya (Pasal 99). ${ }^{24}$

Di samping kewajiban yang dimiliki oleh Komisaris, Komisaris juga mempunyai kewenangan. Kewenangan itu antara lain: ${ }^{25}$

1. Dalam Anggaran Dasar dapat ditetapkan pemberian wewenang kepada Komisaris untuk memberikan persetujuan atau bantuan kepada. Direksi dalam melakukan perbuatan hukum tertentu.

${ }^{21}$ Anisitus Amanat. Op.Cit. Hilm. 140-141.

${ }^{22}$ Ahmad Yani dan Gunawan Widjaja. 2000. Perseroan Terbatas. Jakarta: Raja Grafindo Persada. HIIm.123.

${ }^{23}$ Ibid.

${ }^{24}$ Anisitus Amanat. Op. Cit. Hlm. 141.

${ }^{25}$ C.S.T Kansil. Op.Cit. HIm. 58. 
2. Berdasarkan Anggaran Dasar atau Keputusan RUPS, Komisaris dapat melakukan tindakan pengurusan perseroan dalam keadaan tertentu untuk jangka waktu tertentu. Ketentuan ini memberi wewenang kepada Komisaris untuk melakukan pengurusan perseroan yang sebenarnya hanya dapat dilakukan oleh Direksi dalam hal Direksi tidak ada. Apabila ada Direksi, Komisaris hanya dapat melakukan tindakan tertentu yang secara tegas ditentukan dalam undangundang ini.

3. Bagi Komisaris dalam keadaan tertentu untuk jangka waktu tertentu melakukan tindakan pengurusan sebagaimana dimaksud dalam ayat (2) berlaku semua ketentuan mengenai hak, wewenang dan kewajiban Direksi terhadap perseroan dan pihak ketiga (Pasal 100).

Lama seseorang memangku jabatan Komisaris dalam suatu perseroan terbatas ditetapkan di dalam. Akte Pendirian/Anggaran Dasar. Namun, RUPS dapat memberhentikan untuk sementara waktu Komisaris dari jabatannya sebelum masa tugas yang sebenarnya berakhir. Pemberhentian dan pemberhentian untuk sementara waktu anggota Direksi dari jabatannya seperti diatur dalam Pasal 91 dan 92 ayat (2) sampai dengan ayat (7) menurut ketentuan Pasal 101 ayat (1) UUU Perseroan Terbatas 1995 berlaku juga untuk jabatan Komisaris.

\section{Pembaharuan UU Perseroan Terbatas dalam Kerangka Good Corporate Governance}

Globalisasi ekonomi telah mendorong perusahaan-perusahaan pada suatu negara tidak saja hanya dituntut untuk berkompetisi dengan perusahaan negara lainnya dalam hal kualitas produk yang dihasilkannya, tetapi juga lebih dari itu perusahaan diharapkan dapat memberikan kontribusi yang positif bagi perkembangan ekonomi niegara secara makro.

Untuk dapat mencapai kepada dua tujuan di atas, selayaknya apabila perusahaan dalam menjalankan usahanya dikelola dengan baik. Aspek yang penting untuk diperhatikan bahwa perigelolaan perusahaan bukan saja hanya didasarkan kepada aspek internal perusahaan, tetapi juga tetap harus memperhatikan pada aspek-aspek eksternal perusahaan.

Bagi negara-negara maju pengelolaan perusahan dengan baik sudah merupakan suatu kebutuhan, akan tetapi bagi negaranegara berkembang masalah pengelolaan ini masih menjadi sesuatu yang di "nomor duakan". Oleh karena itu perbaikan pengelolaan perusahaan di negara berkembang harus menjadi prioritas yang utama, apabila ingin memberikan kontribusi bagi perekonomian nasional baik secara mikro maupun makro:

Holly J Gregory dan Marsha E Simms menyatakan bahwa perbaikan pengélolaan perusahaan di negàra-negara berkembañ lebih ditujukan kepada pasar sekuritas yang berkembang baik dengan peraturan yang adil, hukum yang menghargai legitimitas. pemegang saham, dan perlindungan atas hakhak pemillik saham. Akan tetapi banyak pula negara berkembang dengan pasar potensial belum mengembangkan sistem hukum dan 
peraturan, kapasitas penegakan dan' sektor institusi privat yang diperlukan untuk mendorong pengelolaan perusahaan yang efektif. Karena itu menurutnya, usaha reformasi pengelolaan perusahaan di negara-negara berkembang perlu difokuskan pada kerangka fundamental. ${ }^{26}$

Ketika negara-negara di Asia ditempak krisis masalah reformasi pengelolaan perusahaan ini dirasa semakin mendesak keberadaannya. Berdasarkan pada realitas ini, Organization for Economic and Development (OECD) pada bulan April 1999 mengelurkan suatu kumpulan pedoman prinsip pengelolaan perusahaan yang terdiri dari empat prinsip pokok. Prinsip-prinsip itu antara lain: Pertama keadilan (fairness), prinsip ini menyatakan kerangka pengelolaan harus memproteksi hak-hak pemegang saham. Kedua transparan (transparancy), prinsip ini menyatakan bahwa kerangka pengelolan perusahaan harus dapat memastikan bahwa pengungkapan yang akurat dan tepat diadakan sekaitan dengan materi yang menyangkut perusahaan, termasuk situasi keuangan, kinerja, kepemilikan dan kepemimpinan daru suatu perusahäan. Ketiga prinsip pertanggungjawaban (responsibility), yang menyatakan bahwa kerangka pengelolaan perusahaan harus memastikan pedoman strategis dari suatu perusahaan, pengawasan éfektif atas pengelolaan dewan dan pertanggungjawaban dewan kepada perusahaan dan para pemegang saham.
Prinsip terakhir tanggungjawab (accountability), yang menyatakan bahwa kinerja pengelolaan perusahaan harus mengakui hak publik umum (shareholders) sebagaimana diakui dalam hukum dan mendorong kerja sama yang aktif antara perusahaan dan publik (stakeholders) dalam menciptakan kemakmuran, kesempatan keja, dan pendukung perusahaan bersifat finasial., ${ }^{27}$

Pengelolaan perusahaan dengan baik yang didasarkan pada empat prinsip di atas ini diperistilahkan dengan sebuatan good corporate governance. Good corporate governance sebenarnya bukan hal yang baru. Konsep ini mulai mencuat di Amerika Serikat pada tahun 1980-an. Perilaku manajemen perusahaan yang seenaknya, banyak mengundang protes pemegang saham selaku pemilik perusahaan. Mereka memberikan respons atas akuisis dan hostile takeover yang dilakukan dengan menghalalkan berbagai cara. $^{28}$

Pengertian corporate governance menurut sebagian besar pedoman yang dikeluarkan oleh organisasi internasional seperti OECD atau negara-negara maju mengacu kepada hubungan antara semua pihak yang menentukan arah dan performance suatu perusahaan. Di sisi lain corporate governance ini merupakan suatu peristilahan yang relaitif baru yang digunakan untuk suatu konsep lamà yakni kewajiban fidusiari dari mereka yang mengontrol perusahaan untuk bertindak bagi

${ }^{25} \mathrm{Holly}$ J. Gregory dan Marsha E. Simms. "Pengelolaan Perusahaan (Corporate Governance): Apa dan Mengapa Hal Tersebut Penting." Makalah disampaikan pada Seminar Keberadaan Good corporate Governance dalam Masyarakat Bisnis Indonesia, Sekarang dan Masa Mendatang. Kerjasama antara Program Magister Hukum Pasca Sarjana UGM dengan Law School of South Caroline Universty, USA. Yogyakarta 2000. HIm.10-11.

${ }^{27}$ lbid. 
kepentingan seluruh pemegang saham, termasuk pemegang saham minoritas. ${ }^{29}$ Asian Development Bank (ADB) menyatakan: ${ }^{30}$

The issue of corporate governance arises because of the sparatation of ownership from control in modern corporations. When salaried managers run companies on behalf of dispersed shareholders. They may not act in shareholders best interest. This agency or moral hazard problem could exist not just between shareholders and manager, but also between controlling and minorty shareholders, between shareholders and creditors and between controlling shareholders and other-stakeholders, including suppliers and workers. A sound corporate governance system should provide effective protection for shareholders and creditors such they are not denied the return on their investment.

Berdasarkan kepada pernyataan dari ADB ini ada beberapa hal yang menarik untuk dikemukakan. Pertama, permasalahan corporate governance meningkat dikarenakan adanya kepemilikan yang terpisah dari pengawasan dalam perusahaan modern. Kedua, bahwa hal pertama tidak akan eksis apabila hanya melibatkan antara pihak pemilik saham dengan manajer, tetapi juga harus melibàtkan pengawasan dari pemilik saham minoritas (minorty shareholders). Ketiganya, sistem corporate governance juga harus memberikan perlindungan kepada pihak pemegang saham, kreditor, dan anak perusahaan (stakeholders).

Untuk efektifnya penerapan good corporate governance, maka'diperlukan adanya pengklasifikasian karakteristik perusahaan. Hal ini tidak terlepas bahwa good corporate governance dalam penerapannya harus memperhatikan juga karkateristik perusahaan. Menurut Suad Husnan ada dua karakteristik perusahaan di antranya:

1. Perusahaan yang kepemilikannya sangat menyebar (dispersed ownership). Dalam tipe perusahaan seperti ini masalah keagenan yang sering timbul adalah antara agent (pihak manajemen) dengan owners (pemegang saham). Masalah ini nampaknya paling sering dijumpai di perusahaaan-perusahaan AS yang terdaftar di NYSE. Diketemukan misalnya, bahwa perusahaan yang kepemilikannya lebih menyebar memberikan imbalan yang lebih besar kepada pihak manajemen dibandingkan dengan perusahaan yang kepemilikannya terkonsentrasi. Untuk.

\footnotetext{
${ }^{28}$ Fokus. "Pelaksanaan Good Corporate Governance Masih Setengah Hati." www.hukumonline.com/ artikel/

${ }^{29}$ Herwidayatmo." Peran Bapepam dalam Penegakan Good Corporate Governance." Makalah disampaikan pada Seminar Keberadaan Good corporate Governance dalam Masyarakat Bisnis Indonesia, Sekarang dan Masa Mendatang. Kerjasama antara Program Magister Hukum Pasca Sarjana UGM dengań Law School of South Caroline Universty, USA. Yogyakarta 2000. HIm.1.

${ }^{30 Z}$ hulang.J.et.al. 2000. "Corporate Governance and Finance in East Asia: Study of Indonesia, Republic of Korea, Malaysia, Philippines, and Thailand. "Asian Development Bank. Volume One. Dikutip oleh Suad Husnan. "Corporate Governance Pengamat terhadap Sektor Korporat dan Keuangan. "Makalah disajikan pada Seminar Sosialisasi Corporate Governance. 21 Juli 2000 di UGM. HIm.1.
} 
memperkecil masalah keagenan ini antara lain dilakukan dengan membuat agar pihak manajemen juga ikut memiliki saham (insider ownership).

2. Perusahaan yang kepemilikannya terkonsentrasi (closely held). Dalam tipe perusahaan seperti ini, timbul dua kelompok pemegang saham, yaitu controlling dan minority sharholders. Karakteristik ini banyak dijumpai untuk perusahaanperusahaan yang terdaftar di Bursa Indonesia (konglomerat) dan Korea (chaebol). Masalah keagenan yang timbul terutama adalah antara controlling dan minority shareholders. Masalah keagenan menjadi makin serius karena seringkali perusahaan yang terdaftar di bursa merupakan salah satu unit usaha dari grup, sehingga masalah self dealing yang dapat merugikan minority shaleholders, sering terjadi.

Dengan demikian kesimpulannya prinsip good corporate governance sesungguhnya merupakan konsep lama, namun untuk implementasi di negara-negara berkembang masalah ini dianggap sesuatu yang relatif baru. Bagi Indonesia masalah good corporate governance ini baru ramai dibicarakan oleh para pelaku bisnis dan pemerintah setelah Indonesia mengalami terpaan badai krisis. Disinyalir runtuhnya perekonomian Indonesia salah satu faktor penyebabnya adalah tidak adanya suatu kesadaran dari pelaku-pelaku bisnis maupun pemerintah dalam menjalankan konsep good corporate governance.

Dugaan ini ini semakin nyata ketiga The Indonesian Institute for Corporation Governance (IICG) mengadakan survai persepsi atau cara pandang IICG terhadap penerapan good corporate governance bagi perusahaan.
Survai bertajuk Good Corporate Governance Perception Index (GCGPI) ini dilakukan terhadap 52 perusahaan publik yang masuk indeks LQ-45 di Bursa Efek Jakarta (BEJ). Indeks persepsi good corporàte governance ini mengacu kepada 7 kriteria dengan 40 pertanyaan:

Berdasarkan pada kriteria dan pertanyaan di atas, ditemukan hasil-hasil sebagai berikut: Pertama, sebagian besar responden ternyata masih menganggap penerapan good corporate governance sebagai ketaatan terhadap regulasi. Jadi, bukan sebagai kebutuhan untuk menerapkan praktik terpuji sesuai konsep good corporate governance, apalagi untuk menjadikan perusahaan lebih transparan, sehat, dan berkembang. Kedua, dewan komisaris dianggap oleh sebagian besar perusahaan merupakan kumpulan orang-orang yang terseleksi dan profesional. Dari sekian perusahaan hanya satu responden hanya satu perusahaan yang memberikan pengenalan kepada anggota komisaris baru yang diangkat (komisaris independen). Ketiga, Untuk masalah transparasi dan akutabilitas sebagian perusahaan publik sudah menyampaikan informasi ke publik, tetapi kualitas informasi yang disampaikan dalam laporan tahunan masih perlu diperbaiki, terutama menyangkut pengungkapan resiko yang dihadapi perusahaan, termasuk contingency plan.

Dengan demikian dapat dikatakan bahwa penerapan prinsip good corporate governance belumlah dapat dilaksanakan secara optimal dilingkungan perusahaan di Indonesia. Kurangnya aturan-aturan hukum yang didasarkan pada prinsip good corporate governance, lemahnya budaya perusahaan yang mendukung terhadap implementasi prinsip good corporate 


\section{KRITERIA INDEKS PERSEPSI}

\begin{tabular}{|l|l|r|c|}
\hline No. & \multicolumn{1}{|c|}{ Kriteria } & \multicolumn{1}{|c|}{$\begin{array}{c}\text { Jml } \\
\text { Pertanyaan }\end{array}$} & $\begin{array}{c}\text { Prosentase } \\
\text { Bobot }\end{array}$ \\
\hline 1. & Komitmen Perseroan terhadap Implẹmentasi Good Corporate Governance & 3 & $10 \%$ \\
2. & Pelaksanaan RUPST dan Perlakuan terhadap Minorty Shareholders & 6 & $15 \%$ \\
3. & Dewan Komisaris & 10 & $.25 \%$ \\
4. & Struktur Direkși & 7 & $15 \%$ \\
5. & Hubungan dengan Stakeholder & 5 & $15 \%$ \\
6. & Transparasidan Akutabilitas & 7 & $15 \%$ \\
7. & Tanggapan terhadap Riset Good Corporate Governance & 2 & $5 \%$ \\
8. & Jumlah & 40 & $100 \%$ \\
\hline
\end{tabular}

Sumber:www.hukumonline.com.

governance diyakini sebagai alasan dari keadaan tersebut:

Upaya mengadopsi prinsip-prinsip GCG baik dalam aturan yang sifatnya subtantif maupun masuk ke dalam wilayah budaya perusahaan merupakan suatu kebutuhan. Dari segi pengadopsian kepada subtantif hukum sebenarnya merupakan pendekatan yang cenderung lebih mudah, ketimbang mengupayakan pengadopsian dalam budaya perusahaan yang membutuhkan waktu cukup lama.

Dengan rencana dilakukannya pembahanuan UU Perseroan Terbatas, maka hal ini merupakan sarana kongkrit dalam mendorong pengakomodiran prinsip GCG. Minimal ada dua hal penting yang harus dimasukan kedalam pembaharuan UU Perseroan Terbatas dalam kerangka GCG. Pertama, keberadaan Dewan Komisaris Independen; Kedua, laporan keuangan yang mesti dibuat oleh perseroan.

Sementara ini masalah Komisaris Independen hanya ada dalam perseroan yang sifatnya terbuka, sedangkan yang perseroan tertutup cenderung tidak memiliki Komisaris Independen. Dengan tidak adanya Komisaris Independen menyebabkan perseroan yang tertutup banyak melakukan pelanggaran terhadap prinsip fairness dalam GCG. Masalah Komisaris Independen merupakan suatu organ yang sangat penting dibutuhkan dalam ketentuan UU Perseroan Terbatas. Hal ini tentunya akan membawa konsekuensi kepada perseroan terbatas yang didirikan untuk memasukan unsur Komisaris Independen dalam struktur organ perseroan terbatas.

Perseroan dalam membuat laporan keuangan senantiasa mendasarkan diri pada pernyataan standar akuntansi keuangan. 
Pernyataan standar akutansi keuangan ini kalau dicermati lebih banyak memberikan informasi kepada mereka yang memahami betul ilmu akuntasi. Dengan demikian, 'keterbukaan (transparancy) yang diharapkan dari prinsip GCG masih sangat dibatasi jika aturan itu hanya didasarkan pada ketentuan itu. Oleh karena itu, ketentuan tentang pembuatan laporan keuangan seharusnya dibagi kedalam dua bagian; Pertama, sistem laporan keuangan yang menggunakan pernyataan ständar akutansi keuangan; dan, Kedua, sistem laporan keuangan yang diperuntukkan bagi kalangan masyarakat secara luas.

\section{Simpulan}

Masalah GCG merupakan kebutuhan dalam pembaharuan UU Perseroan Terbatas. Hal ini dimaksudkan supaya perseroan baik yang tertutup maupun yang terbuka dapat mengimplementasikan prinsip GCG secara konsisten. Ada dua hal pokok yang dibutuhkan dalam pembaharuan UU Perseroan Terbatas berkaitan dengan prinsip GCG, yakni masalah keberadaan komisaris independen dan masalah laporan keuangan dari suatu perseroan terbatas:
Daftar Pustaka - :

Ali, Chaidir. 1999. Badan hukum. Bandung: Alumni.

Amanat. Anisitus. 1995. Pembahasan Undang-Undang

Perseroan Terbatas 1995 dan Penerapannya dalam Akta Notaris.' Jakarta: Raja Grafindo Persada.

Arifuddin, Ery. "Tanggung: Jawabab Diréksi dalam Pembelian Kembali Saham oleh Perseroan Terbatas." Jurnal Hukum dan Keadilan Vol. 2 No. 1 Oktober 1999.

Black, Henry Campbell . 1991. Black's Law Dictionary. USA: St Paul Minn.

Chatamarrasjid. 2000. Menyingkap Tabir Perseroan (Piercing The Corporate Veil) Kapita Selekta Hukum Perusahaan. Bandung: Citra Aditya Bakti.

Fokus. "Pelaksanaan Good Corporate Governance Masih Setengah Hati." www. hukumonline.com/artikel/

Gautama, Sudargo. 1995. Komentar Atas Undang-Undang.

Perseroan Terbatas (Baru) Tahun 1995 No. 1 Perbandingan dengan Peraturan Lama. Bandung: Citra Aditya Bakti.

Gregory, Holly J. dan Marsha E. Simms. "Pengelolaan Perusahaan (Corporate Governance): Apa dan Mengapa Hal Tersebuit Penting."' Makalah disampaikan pada Seminar Keberadaan Good corporate Governance dalam Masyarakat Bisnis Indonesia, Sekarang dan Masa Mendatang. Kerjasama antara Pro- 
gram Magister Hukum Pasca: Sarjana UGM dengan Law School of South Caroline Universty, USA. Yogyakarta 2000.

Himawan. Charles. "Business Law: Contract and Business Associations" Survey of Indonesian Economic Law Padjadjaran Universty Faculty of Law. Bandung: Lembaga Penelitian Hukum dan Kriminologi' FH UNPAD.

Herwidayatmo." Peran Bapepam dalam Penegakan Good Corporate Governance." Makalah disampaikan pada Seminar Keberadaan Good corporate Governance dalam Masyarakat Bisnis Indonesia, Sekarang dan Masa Mendatang. Kerjasama antara Program Magister Hukum Pasca Sarjana UGM dengan Law School of South Caroline Universty, USA. Yogyakarta 2000.

Himawan, C.S.T . 1995. Hukum Perusahaan Indonesia (Aspek Hukum dalam Ekonomi). Jakarta: PT. Pradnya Paramita.

Khairandy, Ridwan, et. al. 1999. Pengantar Hukum Dagang Indonesia I. Yogyakarta: Pusat Studi Hukum FH UII. Muhammad, Abdulkadir. 1996. Hukum Perseroan Indonesia. Bandung: Citra
Aditya Bakti.

1999. Hukum Perusahaan. Bandung: Citra Aditya Bakti.

Syahrani, Ridwan. 1999. Rangkuman Intisari IImu Hukum. Bandung: Citra Aditya Bakti.

T egar, Moenaf H. 2000. Dewan Komisaris Peranannya sebagai Organ Perseroan. Jakarta: Bumi Aksara.Yani, Ahmad dan, Gunawan Widjaja. 2000. Perseroan Terbatas. Jakarta: Raja Grafindo Persada.

Widjayal, G. Rai. 2000. Hukum Perusahaan Perseroan Terbatas. Jakarta: Megapoin.

Zhuang. J.et.al. 2000. "Corporate Governance and Finance in East Asia: Study of Indonesia, Republic of Korea, Malaysia, Philippines, and Thailand." Asian Development Bank. Volume One. Dikutip oleh Suad Husnan. "Corporate Governance Pengamat terhadap Sektor Korporat dan Keuangan." Makalah disajikan pada Seminar Sosialisasi Corporate Governance. 21 Juli 2000 di UGM.

\section{Peraturan Perundang-undangan}

UU No. 1 Tahun 1995 tentang Perseroan Terbatas 